\title{
The Effects of Palmitic Acid on Nitric Oxide Production by Rat Skeletal Muscle: Mechanism via Superoxide and iNOS Activation
}

\author{
Rafael Herling Lambertuccia ${ }^{a, b} \quad$ Carol Góis Leandro ${ }^{c}$ Marco Aurélio Vinolo ${ }^{a}$ \\ Renato Tadeu Nachbar ${ }^{a}$ Leonardo dos Reis Silveira ${ }^{a}$ Sandro Massao Hirabara ${ }^{a, b}$ \\ Rui Curia Tania Cristina Pithon-Curib \\ aDepartment of Physiology and Biophysics, Institute of Biomedical Sciences, University of São Paulo, \\ São Paulo; ${ }^{b}$ Post-Graduate Program in Human Movement Sciences, Biological Sciences and Health \\ Center, Cruzeiro do Sul University, São Paulo, Brazil; cDepartment of Nutrition, Federal University of \\ Pernambuco - UFPE-CAV, Recife
}

\section{Key Words}

Fatty acids $•$ Nitric oxide synthase $•$ Nuclear factor-kappa B

\begin{abstract}
Background: Increased plasma concentrations of free fatty acids (FFA) can lead to insulin resistance in skeletal muscle, impaired effects on mitochondrial function, including uncoupling of oxidative phosphorylation and decrease of endogenous antioxidant defenses. Nitric oxide (NO) is a highly diffusible gas that presents a half-life of 5-10 seconds and is involved in several physiological and pathological conditions. The effects of palmitic acid on nitric oxide (NO) production by rat skeletal muscle cells and the possible mechanism involved were investigated. Methods: Primary cultured rat skeletal muscle cells were treated with palmitic acid and NO production was assessed by nitrite measurement (Griess method) and 4,5-diaminofluorescein diacetate (DAF-2-DA) assay. Nuclear factor-kappa B (NF- $\kappa$ B) activation was evaluated by electrophoretic mobility shift assay and iNOS protein content by western blotting. Results: Palmitic acid treatment increased nitric oxide production. This effect was abolished by treatment with NOS inhibitors, L-nitro-arginine (LNA) and L-nitro-arginine methyl esther (L-NAME). NF- $\kappa B$ activation and iNOS content were increased due to palmitic acid treatment. The participation of superoxide on nitric oxide production was investigated by incubating the cells with DAF-2-DA in the presence or absence of palmitic acid, a superoxide generator system (X-XO), a mixture of NOS inhibitors and SOD-PEG (superoxide dismutase linked to polyethylene glycol). Palmitic acid and X-XO system increased NO production and this effect was abolished when cells were treated with NOS inhibitors and also with SODPEG. Conclusions: In summary, palmitic acid stimulates NO production in cultured skeletal muscle cells through production of superoxide, nuclear factor-kappa B activation and increase of iNOS protein content.

Copyright $\odot 2012$ S. Karger AG, Basel

Rafael Herling Lambertucci

Department of Physiology and Biophysics, Institute of Biomedical Sciences,

University of Sao Paulo, Av. Prof. Lineu Prestes 1524, 05508-900, Sao Paulo, SP (Brazil)

E-Mail rhlamber@yahoo.com.br
\end{abstract}




\section{Introduction}

The ability to maintain skeletal muscle contraction is mainly dependent upon oxidation of fatty acids and glucose. Carbohydrate is predominantly used during high intensity muscle contraction (glucose uptake can increase as much as 50-fold) [1], whereas fatty acids are the predominant fuel during low to moderate intensity muscle contraction (for review see [2]). These metabolic events are associated with increased production of reactive oxygen (ROS) and reactive nitrogen (RNS) species in skeletal muscle [3, 4]. Superoxide and nitric oxide are the two main reactive species produced (a ROS and a RNS, respectively).

Nitric oxide (NO) is a highly diffusible gas that presents a half-life of 5-10 seconds and is involved in several physiological and pathological conditions [5]. NO acts as modulator of skeletal muscle contraction, glucose transport in skeletal muscle and adipocytes, blood flow and force generation in skeletal muscle [6-8]. These effects occur partially through changes in gene expression and mitochondrial function $[8,9]$.

NO is synthesized from L-arginine by nitric oxide synthase (NOS) using NADPH and oxygen as co-substrates [10]. Three isoforms of NO synthase have been described: neuronal (nNOS or NOS 1), inducible (iNOS or NOS 2) and endothelial (eNOS or NOS 3) [11]. In skeletal muscle cells, eNOS is localized in mitochondria and nNOS is associated with the dystrophin complex in the sarcolemma. iNOS is expressed at very low levels in skeletal muscle, however, under the effect of proinflammatory cytokines, such as tumor necrosis factor alpha (TNF- $\alpha$ ) and interleukin-1beta (IL-1 $\beta$ ) $[12,13]$, iNOS expression can be markedly elevated. iNOS expression is regulated by PPAR (alpha and gamma) and the nuclear factor kappa B (NF- $\mathrm{B}$ ) $[14,15]$.

Increased plasma concentrations of free fatty acids (FFA) lead to insulin resistance in skeletal muscle [16]. In addition, high intracellular concentrations of FFA have impairing effects on mitochondrial function, including uncoupling of oxidative phosphorylation and decrease of endogenous antioxidant defenses (e.g. reduction of intracellular gluthathione content) [17]. Palmitic acid is one of the most abundant fatty acid in plasma of human and rodents and represents $22-25 \%$ of the total fatty acids $[18,19]$. We recently reported increased production of superoxide by palmitic acid oxidation in primary cultured rat skeletal muscle cells [20]. Rachek et al. [21] showed increased production of RNS by palmitic acid $(0.5,1$ and $2 \mathrm{mM})$ in L6 rat skeletal muscle cells. In spite of this observation, the precise mechanisms by which FFA modulate NO generation still remain unknown.

The aim of the present study was to examine the effect of palmitic acid on nitric oxide production by rat skeletal muscle cells and the possible mechanism involved. The present work is the first to investigate the effect of palmitic acid on NO production by primary cultured rat skeletal muscle cells. This experimental protocol was used to avoid the interference of endothelial cells, an important generating site of NO that could mask the NO production by skeletal muscle, which may occur in whole skeletal muscle preparations (muscle incubation).

\section{Materials and Methods}

The experimental procedure of this study was approved by the Ethical Committee of the Institute of Biomedical Sciences, University of São Paulo (Protocol 137, page 24, book 2).

\section{Primary culture of rat skeletal muscle cells}

Primary culture of rat skeletal muscle cells was performed as previously described by others [22] and in our studies $[20,23]$. Wistar rats weighing approximately $100 \mathrm{~g}$ were used in the experiments. Briefly, soleus, gastrocnemius, and quadriceps muscles were dissected, cut into small pieces and digested with $2 \%$ type II collagenase, $0.25 \%$ trypsin and $0.1 \%$ DNAse for isolation of myoblasts. Cells were placed into plates of 6 wells (250,000 cells per well) in DMEM (Dulbecco's Modified Eagle Medium) containing 1\% penicillin, $10 \%$ fetal bovine serum and $10 \%$ horse serum. After 2-3 days of culture, myoblasts were differentiated into skeletal muscle cells in DMEM containing 10\% horse serum for 4-5 days. Palmitic acid (Sigma, St. Louis, 
MO) was dissolved in ethanol (4 mM fatty acid solution) and prepared immediately before each experiment. Control cells were exposed to the same volume of the fatty acid vehicle ( $0.5 \%$ ethanol).

\section{Determination of palmitic acid cytotoxicity}

The cytotoxicity of palmitic acid was assessed by flow cytometry, as described in our previous study [24], after treatment of cells for $3 \mathrm{~h}$ with this fatty acid at $25 \mu \mathrm{M}$. At the end of the culture period, trypsin was added to the medium and cell membrane integrity was then evaluated. Briefly, $50 \mu \mathrm{L}$ of a propidium iodide (PI) solution (100 mg/mL in saline buffer) were added to the cells. After $5 \mathrm{~min}$ incubation at room temperature, the cells were examined in a FACScalibur flow cytometer (Becton Dickinson, CA, USA) by using the Cell Quest software. Fluorescence was measured using the FL2 channel (Orange-red fluorescence $585 / 42 \mathrm{~nm}$ ). Ten thousand cells were analyzed per experiment.

\section{Effect of palmitic acid on nitric oxide production}

The effect of palmitic acid on NO production by primary cultured rat skeletal muscle cells was examined by two methods: nitrite measurement [25] and with the use of the fluorescent compound 4,5-diaminofluorescein diacetate (DAF-2-DA) (Molecular Probes, Eugene, OR, USA) [26]. DAF-2 selectively traps NO between two amino groups yielding the fluorescence of triazolofluorescein [27].

In the nitrite measurement method, cells were incubated at $37^{\circ} \mathrm{C}$ for one hour in the absence or presence of palmitic acid $(25 \mu \mathrm{M})$. The samples were then immediately frozen and stored at $-80^{\circ} \mathrm{C}$ for further analysis. Briefly, $100 \mu \mathrm{L}$ of medium were incubated with an equal volume of Griess reagent $(1 \%$ sulfanilamide $/ 0.1 \%$ naphthylethylene diamine $/ 2.5 \% \mathrm{H}_{3} \mathrm{PO}_{4}$ ) at room temperature for $10 \mathrm{~min}$. After that, absorbance was measured at $550 \mathrm{~nm}$. Nitrite was determined by using sodium nitrite as standard. Cell-free medium contained 0.2 to $0.3 \mathrm{nmol}$ of nitrite per well. This concentration of nitrite was determined in each experiment and subtracted from the value obtained with cells.

For the measurement with DAF-2-DA, samples were treated for $30 \mathrm{~min}$ with the fluorescent compound (final concentration of $10 \mu \mathrm{M}$ in Dulbecco's Phosphate Buffered Saline - DPBS - containing $5 \mathrm{mM}$ glucose) and then incubated at $37^{\circ} \mathrm{C}$ for one hour in the presence or absence of palmitic acid $(25 \mu \mathrm{M})$. After this period, cells were analyzed in a fluorescence microscope. The fluorescence intensity was quantified using the ImageJ 1.43 software (Wayne Rasband, NIH, USA, http://rsb.info.nih.gov/ij/).

\section{Superoxide participation in the nitric oxide production}

The influence of superoxide on NO production by primary cultured rat skeletal muscle cells was investigated by the addition of a superoxide generator system (xanthine oxidase (XO) and its substract xanthine (X)). Firstly, a control assay was performed to confirm the specificity of this generator system. Superoxide production, in the presence of this superoxide generator system, was evaluated by using the dihydroethidium (DHE) oxidation method [28]. The activity of xanthine oxidase $(0.2 \mathrm{U} / \mathrm{mL})$ and the concentration of xanthine $(5 \mu \mathrm{M})$ were the same previously used by Flohe and Otting [29]. A control group without XO and another group with palmitic acid $(25 \mu \mathrm{M})$ only were also included. Briefly, DHE at $1 \mu \mathrm{M}$ (final concentration in DPBS containing $5 \mathrm{mM}$ glucose) was added to the cells $30 \mathrm{~min}$ before the addition of palmitic acid or XO. One hour later, cells were analyzed in a fluorescence microscope. The fluorescence intensity was quantified as described above.

NO production was then evaluated using the fluorescent DAF-2-DA (Molecular Probes, Eugene, OR, USA) [26], as previously described. For that, skeletal muscle cells were treated with XO or palmitic acid in the presence or absence of SOD-PEG (superoxide dismutase linked to polyethylene glycol), an antioxidant enzyme involved in the dismutation of superoxide, at $100 \mathrm{U} / \mathrm{mL}$, or with a mixture of L-nitro-arginine (LNA) and L-nitro-arginine methyl ester (L-NAME) (NOS inhibitors) at $500 \mu \mathrm{M}$.

\section{Determination of nNOS, eNOS and iNOS protein content}

After one hour of incubation at $37^{\circ} \mathrm{C}$ in the absence or presence of palmitic acid $(25 \mu \mathrm{M})$, skeletal muscle cells were homogenized in extraction buffer (100 mM Trizma, pH 7.5; 10 mM EDTA; 100 mM NaF; $10 \mathrm{mM}$ sodium pyrophosphate; $10 \mathrm{mM}$ sodium orthovanadate; $2 \mathrm{mM}$ phenylmethanesulfonyl fluoride; $0.01 \mathrm{mg} / \mathrm{mL}$ aprotinin; at $4^{\circ} \mathrm{C}$ ) for $30 \mathrm{~s}$. After homogenization, triton-X-100 was added at $1 \%$ and samples incubated for $30 \mathrm{~min}$ at $4^{\circ} \mathrm{C}$. Samples were centrifuged at $13,000 \times \mathrm{g}$ for $20 \mathrm{~min}$ at $4^{\circ} \mathrm{C}$. Aliquots of supernatants $(5 \mu \mathrm{L})$ were then used for the measurement of total protein content as described by Bradford [30]. Equal 
amounts of proteins of each sample $(75 \mu \mathrm{g})$ were submitted to electrophoresis and immunoblotting with the specific antibody as described by Towbin [31]. Briefly, proteins of the gel were transferred to a nitrocellulose membrane at $120 \mathrm{~V}$ for $1 \mathrm{~h}$. Non-specific bounds were blocked by incubating the membranes with 5\% defatted milk in basal solution (10 mM Trizma, pH 7.5; $150 \mathrm{mM} \mathrm{NaCl;} \mathrm{0.05 \%} \mathrm{Tween} \mathrm{20),} \mathrm{at} \mathrm{room}$ temperature, for $2 \mathrm{~h}$. Membranes were washed 3 times for 10 min each in basal solution and then incubated with specific antibodies for nNOS, eNOS and iNOS (1:1,000 dilution) in basal solution containing 3\% defatted milk, at room temperature, for $3 \mathrm{~h}$. Membranes were washed again ( 3 times for $10 \mathrm{~min}$ each) and incubated with anti-IgG antibody (1:10,000 dilution) linked to horseradish peroxidase in basal solution containing 1\% defatted milk, at room temperature, for $1 \mathrm{~h}$. Following the washings again, membranes were incubated with substrate for peroxidase and chemiluminescence enhancer (ECL Western Blotting System Kit, GE Health Care, Little Chalfont, Buckinghamshire, England) for $1 \mathrm{~min}$ and immediately exposed to X-ray film. Films were then revealed in the conventional manner. Band intensities were quantified by optical densitometry (ImageJ 1.43, Wayne Rasband, NIH, USA, http://rsb.info.nih.gov/ij/). The results were normalized to Ponceau S staining [32].

To evaluate the possible participation of superoxide in the iNOS expression, the same experiment described above was performed in the presence of SOD-PEG $(100 \mathrm{U} / \mathrm{mL})$.

\section{Electrophoretic mobility shift assay}

$\mathrm{NF}-\kappa \mathrm{B}$ activation was evaluated after treatment of the cells with $25 \mu \mathrm{M}$ palmitic acid for $1 \mathrm{~h}$. Nuclear extract from skeletal muscle cells was obtained as previously described [33]. Double-stranded oligonucleotides containing the NF- $\kappa B$ (5'-AGTTGAGGGGACTTTCCCAGGC-3') consensus binding site [34] were end-labeled using T4 PNK and $\left[\gamma^{32} \mathrm{P}\right]$ ATP (Amersham Biosciences). Binding reactions of the probes $(30,000 \mathrm{cpm})$ were performed with $10 \mu \mathrm{g}$ protein from nuclear extract, at room temperature, for $20 \mathrm{~min}$, in $20 \mu \mathrm{L}$ binding buffer consisting of $20 \mathrm{mM}$ HEPES, pH 7.6, $50 \mathrm{mM} \mathrm{KCl}, 10 \%$ glycerol, $0.2 \mathrm{mM}$ EDTA, $1 \mathrm{mM}$ DTT and $2 \mu \mathrm{g}$ polydeoxyinosinic-deoxycytidylic acid (poly[dI-dC]). Competitive binding assays were conducted under the same conditions with the addition of 2 pmol (100-fold molar excess) unlabeled competitor oligonucleotides. The DNA-protein complexes were electrophoresed on $4 \%$ non-denaturing polyacrylamide gel, at $4^{\circ} \mathrm{C}$, in $45 \mathrm{mM}$ Tris, $45 \mathrm{mM}$ borate and $1 \mathrm{mM}$ EDTA buffer. The gels were dried and subjected to autoradiography. The blots were analyzed by scanner densitometry (Image Master $1 \mathrm{D}^{\circledR}$, Amersham Biosciences) and the results of binding activity were expressed as arbitrary units. In order to evaluate the possible participation of superoxide in this process, the same experiment described above was performed in the presence of SOD-PEG $(100 \mathrm{U} / \mathrm{mL})$.

\section{Statistical analysis}

The results are presented as mean \pm S.E.M. Statistical analysis of the results was performed by using the one-way analysis of variance (ANOVA) and Tukey's post hoc test, when more than two groups were compared, and by using the Student's t test for comparison between two groups. Results were considered statistically significant for $\mathrm{P}<0.05$. The GraphPad Prism 5 software (Graph Pad Software, Inc., San Diego, CA, USA) was used.

\section{Results}

The cytotoxic effect of palmitic acid was evaluated in cultured cells treated with $25 \mu \mathrm{M}$ palmitic acid (concentration used in all assays) for $3 \mathrm{~h}$. At this concentration of palmitic acid no loss of plasma membrane integrity was observed. The percentage of viable cells in the control group and in the group treated with palmitic acid was the same (96\% for both groups) (Fig. 1).

NO production was assessed by measurement of nitrite and by intracellular DAF-2-DA fluorescence. As indicated in the two methods used, palmitic acid elevated NO production in skeletal muscle cells (Fig. 2A and 2B). The efficiency of the measurement of nitric oxide production by using the fluorescent compound DAF-2-DA was tested in the presence of a mixture of LNA and L-NAME (NOS inhibitors) at $500 \mu \mathrm{M}$, to ensure the inhibition of all three 
Fig. 1. Effects of palmitic acid on viability of primary cultured skeletal muscle cells. Cells were treated with $25 \mu \mathrm{M}$ palmitic acid. The values are presented as percentage of viable and non-viable cells.
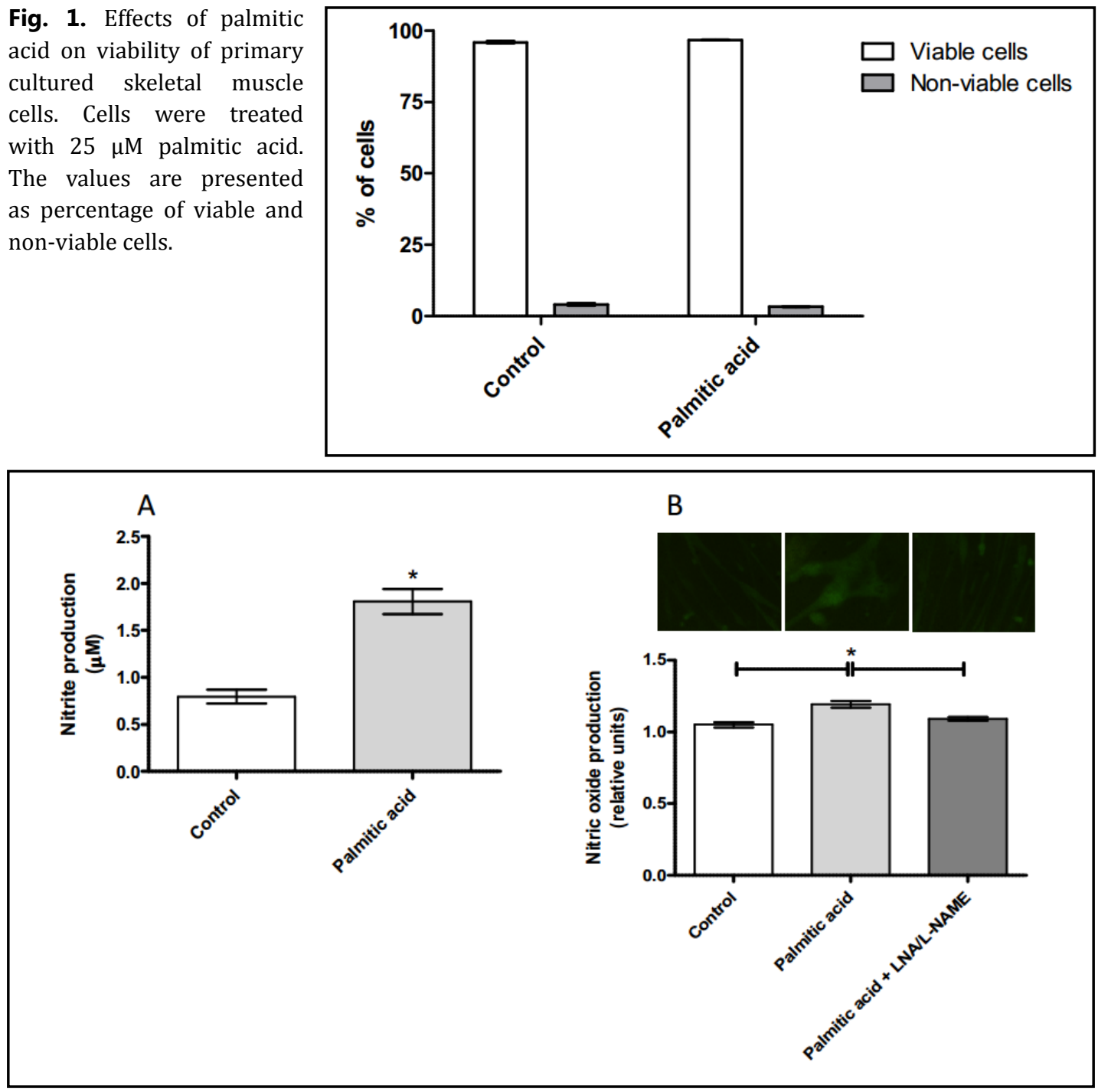

Fig. 2. Effects of palmitic acid on nitric oxide production in skeletal muscle cells as determined by nitrite measurement (A) and by intracellular DAF-2-DA fluorescence assay (B). Muscle cells were incubated for $1 \mathrm{~h}$ with DAF-2-DA $(10 \mu \mathrm{M})$ in the presence or absence of palmitic acid $(25 \mu \mathrm{M})$. NOS inhibitors (LNA and L-NAME) were used as control. Representative examples are shown above the graph. The values are presented as means \pm S.E.M. ${ }^{*} \mathrm{P}<0.001$ for comparison between groups. The results are presented as mean \pm SEM from three experiments.

NOS isoforms (Fig. 2B). The samples containing this mixture presented a significant decrease in NO production confirming the specificity of the method used to detect this RNS.

To evaluate the participation of superoxide on nitric oxide production, cells were incubated with DAF-2-DA $(10 \mu \mathrm{M})$ for $1 \mathrm{~h}$ in the presence or absence of palmitic acid $(25 \mu \mathrm{M})$, a superoxide generator system (X-XO), a mixture of NOS inhibitors (LNA / L-NAME) at $500 \mu \mathrm{M}$ and SOD-PEG $(100 \mathrm{U} / \mathrm{mL})$. Firstly, a control assay was carried out to demonstrate the effect of palmitic acid $(25 \mu \mathrm{M})$ on ROS production, and also to test the specificity of the $\mathrm{X}$-XO system. Both treatments induced a significant increase of ROS production by 1.45 - and 1.9-fold, respectively (Fig. 3). After this control assay, the effect of the increase of superoxide content, induced by palmitic acid and X-XO system, on NO production was evaluated. Palmitic acid and X-XO system increased NO production (by 1.93- and 3.33-fold, respectively). These effects were abolished in cells treated with NOS inhibitors or SOD-PEG (Fig. 4). 
Fig. 3. Control assay: measurement of superoxide production by dihydroethidium oxidation method in the absence and presence of palmitic acid $(25 \mu \mathrm{M}), \mathrm{X}-\mathrm{XO}$ (xanthine oxidase and its substrate xanthine - a superoxide generator system) and X-XO associated with SODPEG enzyme (polyethylene glycolated-superoxide dismutase $) \quad(100 \mathrm{U} / \mathrm{mL})$. Representative examples are shown above the graph. The values are presented as mean \pm SEM. ${ }^{*} \mathrm{P}<0.01$ for comparison between groups. The results are presented as mean \pm SEM from three experiments.

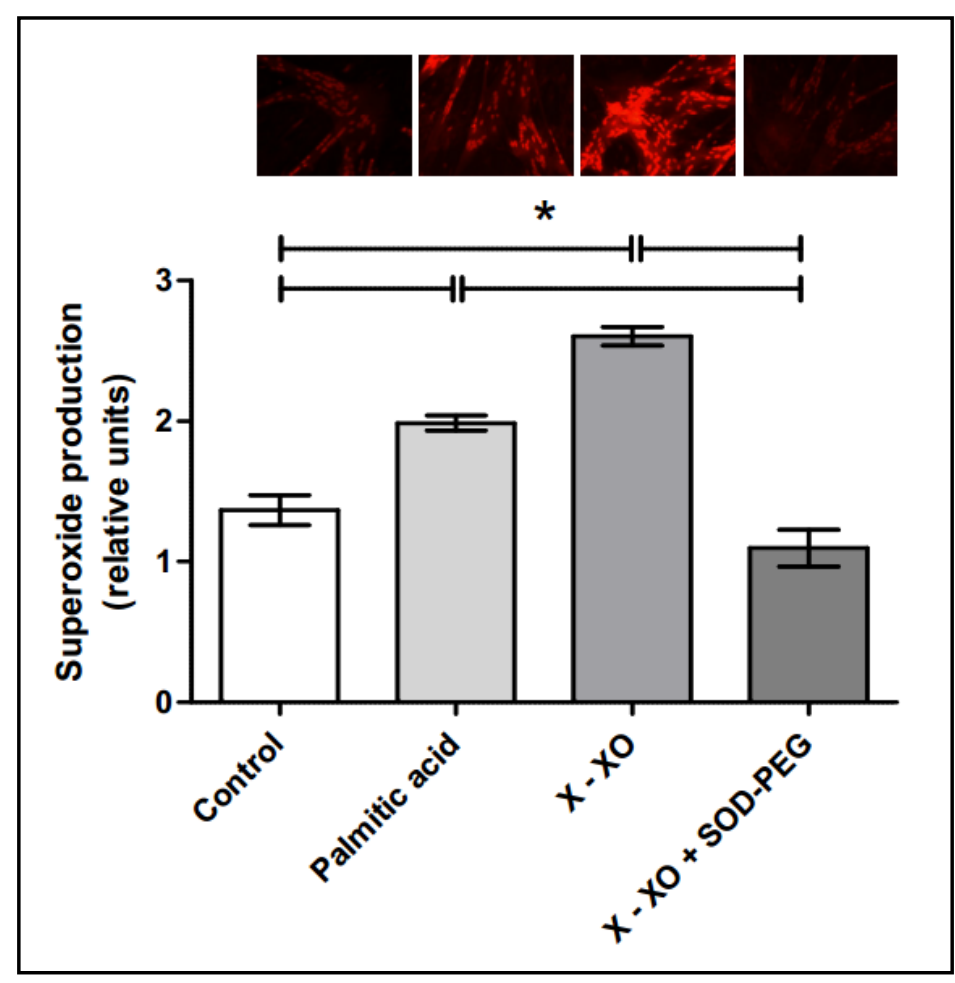

Fig. 4. Effects of superoxide on nitric oxide production in skeletal muscle cells measured by intracellular DAF-2-DA fluorescence assay. Muscle cells were incubated for $1 \mathrm{~h}$ with 4,5-diaminofluorescein diacetate (DAF-2-DA) $(10 \mu \mathrm{M})$ in the presence or absence of palmitic acid $(25 \mu \mathrm{M}), \mathrm{X}$-XO (xanthine oxidase and its substrate xanthine - a superoxide generator system), SOD-PEG enzyme (polyethylene glycolated-superoxide dismutase) $(100 \mathrm{U} / \mathrm{mL})$, and a mixture of NOS inhibitors (LNA and L-NAME) $(500 \mu \mathrm{M})$. The values are presented as means \pm S.E.M. *P $<0.01$ for comparison between groups. The results are presented as mean \pm SEM from three experiments.

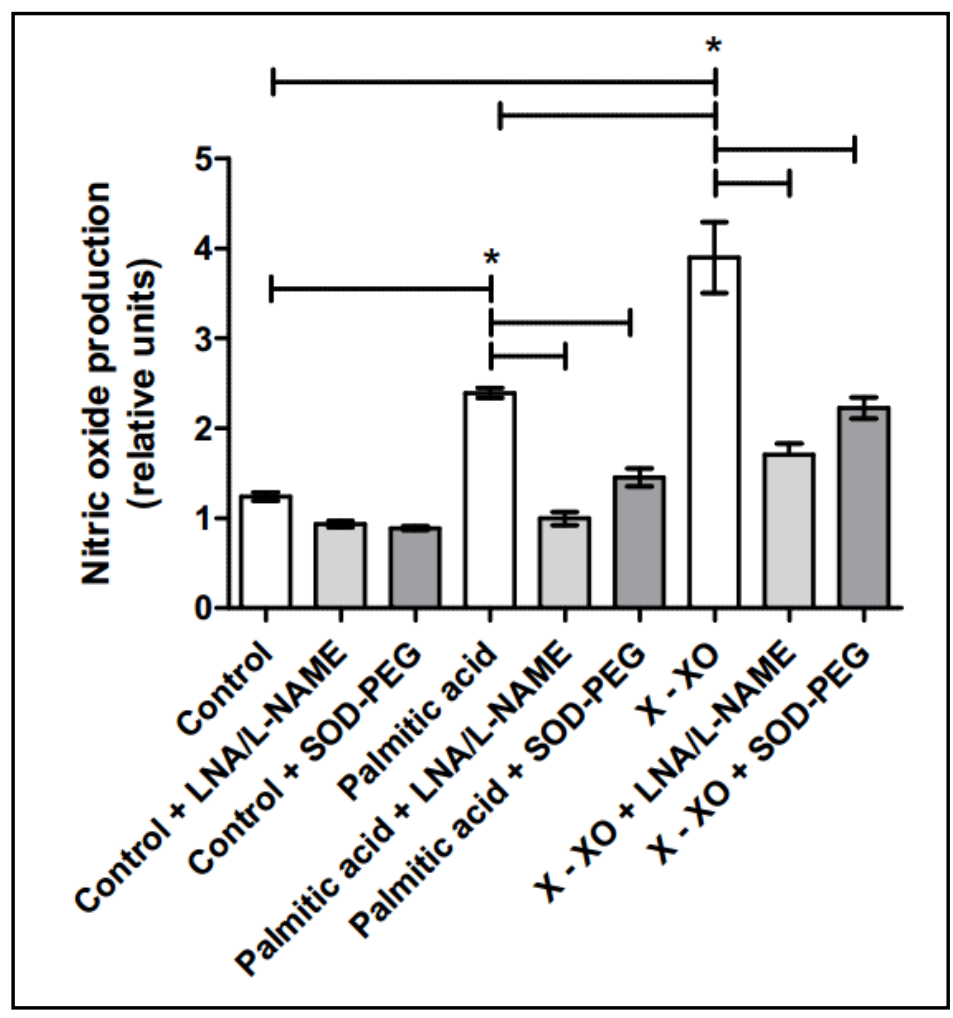

The influence of palmitic acid on NOS expression was then evaluated. The treatment with this fatty acid at $25 \mu \mathrm{M}$ induced a marked increase (1.6-fold) on iNOS expression only when compared with control, as measured by western blotting analysis (Fig. 5). nNOS and eNOS showed no changes with palmitic acid treatment $(1.825 \pm 0.269$ and $1.606 \pm 0.372$, respectively) when compared to control group $(1.905 \pm 0.444)$. NF- $\mathrm{kB}$ activation by palmitic 


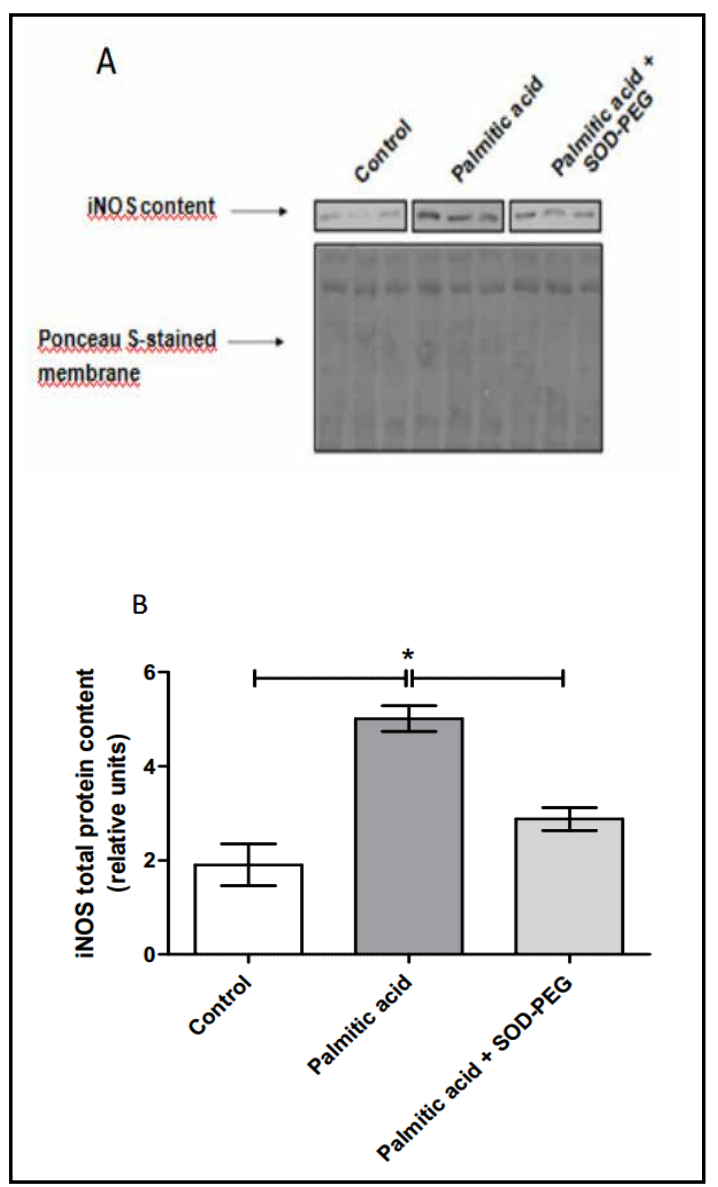

Fig. 5. (A) Representative images of western blotting analyses. (B) Effects of palmitic acid on iNOS expression in skeletal muscle cells. Cells were treated with $25 \mu \mathrm{M}$ palmitic acid in the presence and absence of SOD-PEG enzyme (polyethylene glycolated-superoxide dismutase $)(100 \mathrm{U} / \mathrm{mL})$. Whole cell lysates were dissolved in a sample buffer and submitted to 8\% SDS-PAGE. Western blotting assays were performed using mouse antiiNOS polyclonal antibody. Band intensities were analysed using the ScionImage software (Scion Corporation) and are expressed as relative values. The values are presented as means \pm S.E.M. ${ }^{*} \mathrm{P}<$ 0.001 for comparison between groups. The results are presented as mean \pm SEM from two experiments.
A

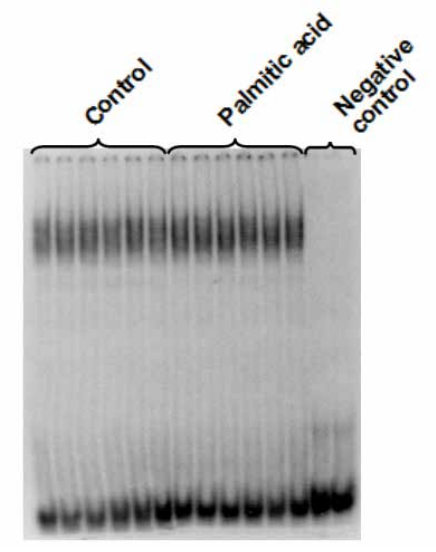

B

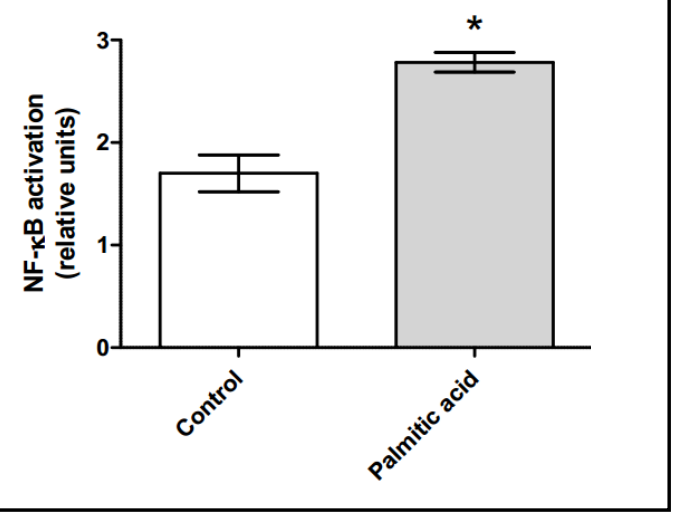

Fig. 6. (A) Representative images of Electrophoretic mobility shift assays. (B) Effects of palmitic acid on NF- $\kappa$ B activation in skeletal muscle cells. Cells were treated with $25 \mu \mathrm{M}$ palmitic acid. Band intensities were analyzed using the ScionImage software (Scion Corporation) and are expressed as relative values. Controls received an arbitrary value of 1 . The values are presented as means \pm S.E.M. ${ }^{*} \mathrm{P}<0.001$ for comparison between groups. The results are presented as mean \pm SEM from two experiments.

acid was also investigated. The treatment of muscle cells with $25 \mu \mathrm{M}$ palmitic acid caused a marked activation (by 1.6-fold) of NF- $\mathrm{KB}$ (Fig. 6).

In order to investigate the participation of ROS in NF- $\mathrm{KB}$ activation by palmitic acid in skeletal muscle cells, the antioxidant enzyme SOD-PEG was added to the culture medium. The activation of NF- $\kappa B$ induced by palmitic acid was abolished by SOD-PEG treatment (Fig. 7). 


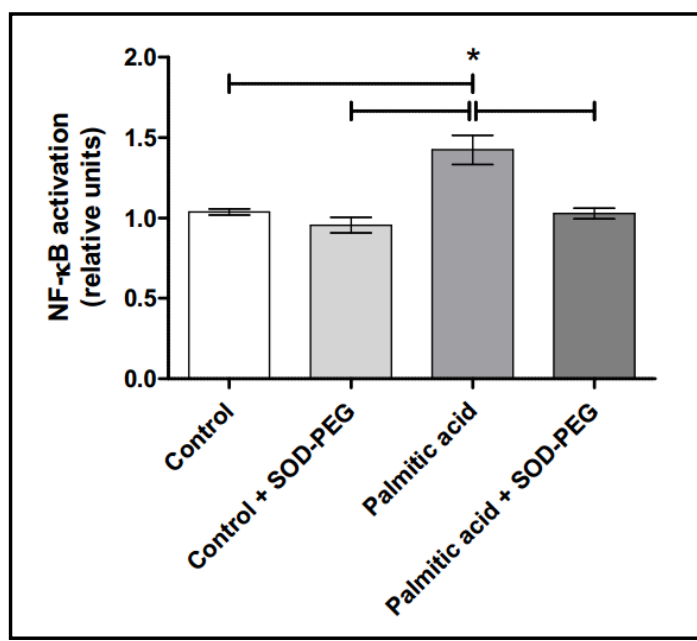

Fig. 7. Effects of palmitic acid on NF- $\kappa B$ activation in skeletal muscle cells evaluated by Electrophoretic mobility shift assay. Cells were treated with $25 \mu \mathrm{M}$ palmitic acid in the presence or absence of SODPEG enzyme (polyethylene glycolated-superoxide dismutase $)(100 \mathrm{U} / \mathrm{mL})$. Controls received an arbitrary value of 1 . The values are presented as means \pm S.E.M. $* \mathrm{P}<0.001$ for comparison between groups. The results are presented as mean \pm SEM from two experiments.

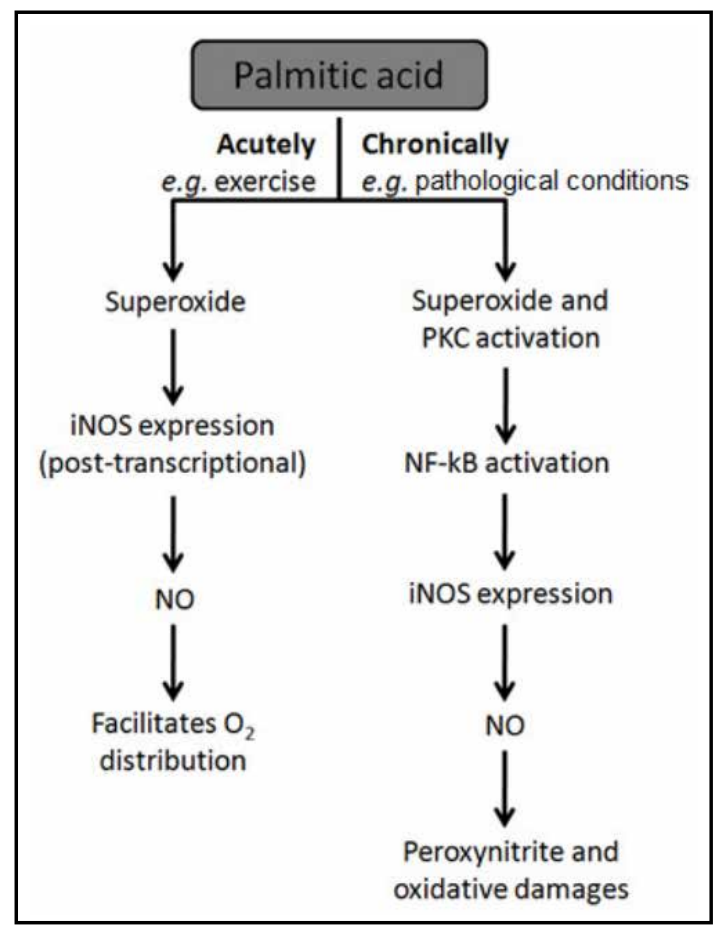

Fig. 8. Flow diagram summarizing the effect of palmitic acid on nitric oxide production in primary cultured rat skeletal muscle cells.

\section{Discussion}

The treatment of skeletal muscle cells with palmitic acid at $25 \mu \mathrm{M}$ increased NO production through superoxide generation, and involved increased iNOS expression, and $\mathrm{NF}-\kappa \mathrm{B}$ activation.

The concentration of palmitic acid used in the present study $(25 \mu \mathrm{M})$ was chosen due to the fact that FFA are highly bound to albumin in plasma, and the unbound fraction is extremely low $[35,36]$. According to Steinberg [37], about $99.5 \%$ of the total FFA are bound to albumin in plasma, being only $0.5 \%$ free. Taking into account that total plasma FFA concentration can exceptionally reach $5 \mathrm{mM}$ in some pathological conditions [38], the unbound fraction can reach up to $25 \mu \mathrm{M}$. According to our previous study [16], the concentration of unbound to albumin FFA is about $8.4 \mu \mathrm{M}$ when the total plasma FFA concentration (bound and unbound) is $270 \mu \mathrm{M}$. Then, it is possible that, under physiological conditions, such as fasting and prolonged exercise or in common disorders (such as obesity and diabetes), when plasma FFA concentration reaches up to $800 \mu \mathrm{M}$, the unbound fraction of FFA is near $25 \mu \mathrm{M}$.

Rachek et al. [21] showed that palmitic acid under certain circumstances can be toxic to skeletal muscle cells. This process involves mitochondrial oxidative stress leading to impaired contraction activity of skeletal muscle and cell death [39]. In the present study, the cells were incubated for $3 \mathrm{~h}$ with $25 \mu \mathrm{M}$ palmitic acid and no signs of cytotoxicity were observed. So, the concentration of $25 \mu \mathrm{M}$ palmitic acid was not toxic to skeletal muscle cells. This concentration of palmitic acid was also used in our previous study to evaluate the effect of this fatty acid on superoxide production by skeletal muscle cells [20].

The effect of $25 \mu \mathrm{M}$ palmitic acid on nitric oxide production by skeletal muscle cells was then investigated. In both methods used, a significant increase of NO production by skeletal muscle cells incubated with palmitic acid was found. Taking into account that palmitic acid increases both NO and superoxide production [20], a possible relationship between the productions of these two reactive species was then evaluated. Cells treated with palmitic 
acid and X-XO system showed a marked increase of NO production, which was abolished in the presence of SOD-PEG. These findings indicate that NO production is stimulated by superoxide generation in skeletal muscle cells.

According to McCann et al. [9], the inducible isoform of NOS (iNOS) does not significantly contribute for the basal production of NO by skeletal muscle. However, once stimulated, NO production can increase up to 1,000 times. Taking this information into account, the expression of iNOS protein in skeletal muscle cells incubated with palmitic acid was evaluated. Interestingly, even after only $1 \mathrm{~h}$ of treatment, an increase in expression of this enzyme was observed. An opposite response was obtained when the cells were treated with SOD-PEG. Again, a key role of superoxide in the control of NO production by skeletal muscle cells was observed. Probably, after this short period of time $(1 \mathrm{~h})$, superoxide may increases iNOS expression by a post-transcriptional mechanism, such as increase of its mRNA stabilization. This event may occur by the regulation of PKC activity. According to Barbieri et al. [40] and Knapp et al. [41], superoxide can induce a direct activation of PKC enzyme activity via thiol modification and modulation of zinc content. Additionally, it was already described that PKC is specifically implicated in the enhanced stability of many labile mRNAs, such as those encoding p21, Bcl-2, IL-1 and iNOS [42]. With that, superoxide may induce an increase of iNOS content due to an optimization of its mRNA stability, what can occur in consequence of PKC activation.

Even though that an acute treatment with palmitic acid can lead to an increased amount of iNOS protein, a longer period of cell exposure to this fatty acid may lead to an increase of iNOS content in a higher extent. The expression of iNOS is regulated by NF- $\kappa B$, and palmitic acid has been described to activate this transcription factor in 3T3-L1 adipocytes, pericytes, L6 myotubes, mouse $\mathrm{C} 2 \mathrm{C} 12$ myoblasts, human promonocytic cell line U937, human endothelial cells and mouse macrophage [43]. It has been also described that, when used three different cell types (monocytic cell line U937, Jurkat T lymphocytes, and peripheral blood $\mathrm{T}$ cells), $\mathrm{NF}-\kappa \mathrm{B}$ activation was easily detected after only 2.5-5 min after stimulation [44]. So, NF- $\kappa \mathrm{B}$ activation was then investigated under the conditions of this study. NF- $\kappa \mathrm{B}$ is a transcription factor composed by members of the Rel family (p50/NF- $\mathrm{BB} 1, \mathrm{p} 65 / \mathrm{RelA}, \mathrm{p} 52 / \mathrm{NF}-\kappa \mathrm{B} 2$, RelB, c-Rel, p105 and p100) usually found in the cytosol as a heterodimer complex being bound to its inhibitory protein IKB [45]. Superoxide induces IkB phosphorylation through activation of IkB kinase (IKK) and leads to dissociation and translocation of NF- $\kappa B$ active complex (p50/p65) to cell nucleus that binds to a specific sequence of DNA [45]. NF- $\kappa B$ regulates expression of several genes involved in the immune and inflammatory responses and cell survival and adhesion [46].

An increase of NF- $\mathrm{\kappa B}$ activation in cells treated with palmitic acid was observed, however, in the presence of the antioxidant enzyme (SOD-PEG) this activation was reduced reaching control values. Similar results were observed in lymphocytes exposed to palmitic acid [47]. Taking together, these findings suggest that exposing cells to palmitic acid can induce an increase of superoxide production, which lead to an activation of NF- $\kappa \mathrm{B}$, a transcription factor responsible to control iNOS expression, that may induce an augment of NO production.

Actually, palmitic acid can induce NF- $\kappa B$ activation in skeletal muscle cells by two ways: (1) through increased production of superoxide after being metabolized and also (2) by accumulation inside the cells, leading to a direct activation of PKC, which in turn phosphorylates and activates IKK [48]. It is already well described that intracellular accumulation of fatty acids has been shown to be cytotoxic $[49,50]$. According to our results both mechanisms can occur in our model once palmitic acid is capable to increase the production of superoxide and NO, which are both toxic to the cells. In addition, NO can react with superoxide to produce peroxynitrite (a more reactive specie), in a much more efficient reaction (3 times faster) than that of superoxide with SOD [7, 9]. Peroxynitrite can nitrate tyrosine residues in a number of proteins [51] and modulates their functions [52].

In opposition to the adverse effects mentioned above, the acute production of NO, as observed during a physical exercise, has an important metabolic role. NO interacts and inhibits, in a reversible manner, the activity of CcO (cytochrome c oxidase - complex IV), an 
enzyme of the mitochondrial electron transport chain $[53,54]$. CcO catalyses the oxidation of cytochrome $c$ and the reduction of oxygen $\left(\mathrm{O}_{2}\right)$ to water in order to produce ATP [54]. NO inhibits $\mathrm{CcO}$ in a competitive manner with $\mathrm{O}_{2}$, leading to a decrease of the affinity of the enzyme for $\mathrm{O}_{2}$, and also by increasing the $\mathrm{Km}$ of $\mathrm{CcO}$ for oxygen, and so modulates mitochondrial respiration [53]. The existence of an isoform of NOS associated to the mitochondrial inner membrane (mtNOS), recently described, can also facilitate the inhibition of $\mathrm{CcO}[55,56]$.

The meaning for the control of NO production by palmitic acid is postulated in the Figure 8. An acute augment of NO production induced by palmitic acid in skeletal muscle cells, during physical exercise, facilitates the $\mathrm{O}_{2}$ distribution in skeletal muscle being particularly important in conditions of low $\mathrm{O}_{2}$ concentration [53]. However, a long time exposure to palmitic acid, that occurs in some specific conditions such as ethanol abuse, cold stress, sepsis, cachexia, diabetes and aging $[38,57,58]$, may induce a high production of peroxynitrite, and consequently higher oxidative damage to skeletal muscle cells causing loss of muscle mass and weakness.

\section{Contributions}

R.H.L. contributed to study design and data interpretation, performed experiments and wrote the manuscript. C.G.L., M.A.V. and R.T.N. performed experiments and edited the manuscript. L.R.S., S.M.H., R.C. and T.C.P contributed to study design, data interpretation and editing of the manuscript. All authors approved the final version of this manuscript.

\section{Acknowledgements}

The authors are indebted to the technical assistance of E. P. Portiolli, G. de Souza, Dr. T. C. Alba-Loureiro and J. R. Mendonça. This research is supported by FAPESP, CNPq and CAPES.

\section{References}

1 Merry TL, McConell GK: Skeletal muscle glucose uptake during exercise: A focus on reactive oxygen species and nitric oxide signaling. IUBMB Life 2009;61:479-484.

- Hirabara SM, Silveira LR, Abdulkader FR, Alberici LC, Procopio J, Carvalho CR, Pithon-Curi TC, Curi R: Role of fatty acids in the transition from anaerobic to aerobic metabolism in skeletal muscle during exercise. Cell Biochem Funct 2006;24:475-481.

3 Ji LL: Oxidative stress during exercise: Implication of antioxidant nutrients. Free Radic Biol Med 1995;18:1079-1086.

4 Fulle S, Protasi F, Di Tano G, Pietrangelo T, Beltramin A, Boncompagni S, Vecchiet L, Fano G: The contribution of reactive oxygen species to sarcopenia and muscle ageing. Exp Gerontol 2004;39:17-24.

5 Badal S, Brown PD, Ragoobirsingh D: Nitric oxide agents impair insulin-mediated signal transduction in rat skeletal muscle. BMC Biochem 2006;7:17.

6 McGrowder D, Ragoobirsingh D, Brown P: Acute effects of exogenous nitric oxide on glucose uptake in skeletal muscle of normoglycaemic and diabetic rats. Med Sci Monit 2006;12:BR28-35.

7 Jackson MJ, Pye D, Palomero J: The production of reactive oxygen and nitrogen species by skeletal muscle. J Appl Physiol 2007;102:1664-1670.

-8 Patwell DM, McArdle A, Morgan JE, Patridge TA, Jackson MJ: Release of reactive oxygen and nitrogen species from contracting skeletal muscle cells. Free Radic Biol Med 2004;37:1064-1072.

9 McCann SM, Mastronardi C, de Laurentiis A, Rettori V: The nitric oxide theory of aging revisited. Ann N Y Acad Sci 2005;1057:64-84. 
Lambertucci/Leandro/Vinolo et al.: Palmitic Acid and Nitric Oxide Production: Superoxide and iNOS Role

10 Marletta MA, Hurshman AR, Rusche KM: Catalysis by nitric oxide synthase. Curr Opin Chem Biol 1998;2:656-663.

11 Grozdanovic Z: No message from muscle. Microsc Res Tech 2001;55:148-153.

12 Vassilakopoulos T, Govindaraju K, Parthenis D, Eidelman DH, Watanabe Y, Hussain SN: Nitric oxide production in the ventilatory muscles in response to acute resistive loading. Am J Physiol 2007;292:L10131022.

13 Song W, Kwak HB, Kim JH, Lawler JM: Exercise training modulates the nitric oxide synthase profile in skeletal muscle from old rats. J Gerontol A Biol Sci Med Sci 2009;64:540-549.

14 Zhou LZ, Johnson AP, Rando TA: Nf kappa b and ap-1 mediate transcriptional responses to oxidative stress in skeletal muscle cells. Free Radic Biol Med 2001;31:1405-1416.

15 Ji LL, Gomez-Cabrera MC, Vina J: Exercise and hormesis: Activation of cellular antioxidant signaling pathway. Ann N Y Acad Sci 2006;1067:425-435.

16 Hirabara SM, Silveira LR, Abdulkader F, Carvalho CR, Procopio J, Curi R: Time-dependent effects of fatty acids on skeletal muscle metabolism. J Cell Physiol 2007;210:7-15.

17 Hickson-Bick DL, Sparagna GC, Buja LM, McMillin JB: Palmitate-induced apoptosis in neonatal cardiomyocytes is not dependent on the generation of ros. Am J Physiol Heart Circ Physiol 2002;282:H656664.

18 Richieri GV, Kleinfeld AM: Unbound free fatty acid levels in human serum. J Lipid Res 1995;36:229-240.

19 Miyasaka CK, Mendonca JR, Nishiyama A, de Souza JA, Pires de Melo M, Pithon-Curi TC, Curi R: Comparative effects of fish oil given by gavage and fish oil-enriched diet on leukocytes. Life Sci 2001;69:1739-1751.

-20 Lambertucci RH, Hirabara SM, Silveira Ldos R, Levada-Pires AC, Curi R, Pithon-Curi TC: Palmitate increases superoxide production through mitochondrial electron transport chain and nadph oxidase activity in skeletal muscle cells. J Cell Physiol 2008;216:796-804.

21 Rachek LI, Musiyenko SI, LeDoux SP, Wilson GL: Palmitate induced mitochondrial deoxyribonucleic acid damage and apoptosis in 16 rat skeletal muscle cells. Endocrinology 2007;148:293-299.

-22 Jensen L, Schjerling P, Hellsten Y: Regulation of vegf and bfgf mrna expression and other proliferative compounds in skeletal muscle cells. Angiogenesis 2004;7:255-267.

-23 Lambertucci RH, Silveira L dos R, Hirabara SM, Curi R, Sweeney G, Pithon-Curi TC: Effects of moderate electrical stimulation on reactive species production by primary rat skeletal muscle cells: Cross talk between superoxide and nitric oxide production. J Cell Physiol 2012;227:2511-2518.

24 Martins de Lima T, Cury-Boaventura MF, Giannocco G, Nunes MT, Curi R: Comparative toxicity of fatty acids on a macrophage cell line (j774). Clin Sci (Lond) 2006;111:307-317.

25 Ding AH, Nathan CF, Stuehr DJ: Release of reactive nitrogen intermediates and reactive oxygen intermediates from mouse peritoneal macrophages. Comparison of activating cytokines and evidence for independent production. J Immunol 1988;141:2407-2412.

-26 Kojima H, Sakurai K, Kikuchi K, Kawahara S, Kirino Y, Nagoshi H, Hirata Y, Nagano T: Development of a fluorescent indicator for nitric oxide based on the fluorescein chromophore. Chem Pharm Bull (Tokyo) 1998;46:373-375.

27 Nagata N, Momose K, Ishida Y: Inhibitory effects of catecholamines and anti-oxidants on the fluorescence reaction of 4,5-diaminofluorescein, daf-2, a novel indicator of nitric oxide. J Biochem 1999;125:658-661.

-28 Fink B, Laude K, McCann L, Doughan A, Harrison DG, Dikalov S: Detection of intracellular superoxide formation in endothelial cells and intact tissues using dihydroethidium and an hplc-based assay. Am J Physiol Cell Physiol 2004;287:C895-902.

29 Flohe L, Otting F: Superoxide dismutase assays. Methods Enzymol 1984;105:93-104.

30 Bradford MM: A rapid and sensitive method for the quantitation of microgram quantities of protein utilizing the principle of protein-dye binding. Anal Biochem 1976;72:248-254.

-31 Towbin H, Staehelin T, Gordon J: Electrophoretic transfer of proteins from polyacrylamide gels to nitrocellulose sheets: Procedure and some applications. Proc Natl Acad Sci U S A 1979;76:4350-4354.

-32 Boengler K, Gres P, Cabestrero A, Ruiz-Meana M, Garcia-Dorado D, Heusch G, Schulz R: Prevention of the ischemia-induced decrease in mitochondrial tom 20 content by ischemic preconditioning. J Mol Cell Cardiol 2006;41:426-430.

33 Andrews NC, Faller DV: A rapid micropreparation technique for extraction of DNA-binding proteins from limiting numbers of mammalian cells. Nucleic Acids Res 1991;19:2499. 
Lambertucci/Leandro/Vinolo et al.: Palmitic Acid and Nitric Oxide Production: Superoxide and iNOS Role

34 Hang CH, Shi JX, Tian J, Li JS, Wu W, Yin HX: Effect of systemic lps injection on cortical nf-kappab activity and inflammatory response following traumatic brain injury in rats. Brain Res 2004;1026:23-32.

35 Hamilton JA, Kamp F: How are free fatty acids transported in membranes? Is it by proteins or by free diffusion through the lipids? Diabetes 1999;48:2255-2269.

-36 Kampf JP, Kleinfeld AM: Is membrane transport of ffa mediated by lipid, protein, or both? An unknown protein mediates free fatty acid transport across the adipocyte plasma membrane. Physiology (Bethesda) 2007;22:7-14.

37 Steinberg H: Regulation of lipid and lipoprotein metabolism. In: Best and taylor's physiological basis of medical practice, ed 7th. Baltimore, Williams \& Wilkins, 1985.

38 Di Paola M, Lorusso M: Interaction of free fatty acids with mitochondria: Coupling, uncoupling and permeability transition. Biochim Biophys Acta 2006;1757:1330-1337.

-39 Martins AR, Nachbar RT, Gorjao R, Vinolo MA, Festuccia WT, Lambertucci RH, Cury-Boaventura MF, Silveira LR, Curi R, Hirabara SM: Mechanisms underlying skeletal muscle insulin resistance induced by fatty acids: Importance of the mitochondrial function. Lipids Health Dis 2012;11:30.

40 Barbieri E, Sestili P: Reactive oxygen species in skeletal muscle signaling. J Signal Transduct 2012;2012:982794.

41 Knapp LT, Klann E: Superoxide-induced stimulation of protein kinase c via thiol modification and modulation of zinc content. J Biol Chem 2000;275:24136-24145.

42 Shim J, Karin M: The control of mrna stability in response to extracellular stimuli. Mol Cells 2002;14:323331.

43 Martins de Lima T, Gorjao R, Hatanaka E, Cury-Boaventura MF, Portioli Silva EP, Procopio J, Curi R: Mechanisms by which fatty acids regulate leucocyte function. Clin Sci (Lond) 2007;113:65-77.

44 Brown K, Park S, Kanno T, Franzoso G, Siebenlist U: Mutual regulation of the transcriptional activator nfkappa b and its inhibitor, i kappa b-alpha. Proc Natl Acad Sci U S A 1993;90:2532-2536.

-45 Ji LL, Gomez-Cabrera MC, Steinhafel N, Vina J: Acute exercise activates nuclear factor (nf)-kappab signaling pathway in rat skeletal muscle. Faseb J 2004;18:1499-1506.

46 Pahl HL: Activators and target genes of rel/nf-kappab transcription factors. Oncogene 1999;18:6853-6866.

47 Takahashi HK, Cambiaghi TD, Luchessi AD, Hirabara SM, Vinolo MA, Newsholme P, Curi R: Activation of survival and apoptotic signaling pathways in lymphocytes exposed to palmitic acid. J Cell Physiol 2012;227:339-350.

48 Jove M, Planavila A, Laguna JC, Vazquez-Carrera M: Palmitate-induced interleukin 6 production is mediated by protein kinase $\mathrm{c}$ and nuclear-factor kappab activation and leads to glucose transporter 4 downregulation in skeletal muscle cells. Endocrinology 2005;146:3087-3095.

49 Boden G, Lebed B, Schatz M, Homko C, Lemieux S: Effects of acute changes of plasma free fatty acids on intramyocellular fat content and insulin resistance in healthy subjects. Diabetes 2001;50:1612-1617.

50 Blaak EE: Basic disturbances in skeletal muscle fatty acid metabolism in obesity and type 2 diabetes mellitus. Proc Nutr Soc 2004;63:323-330.

51 Bartesaghi S, Ferrer-Sueta G, Peluffo G, Valez V, Zhang H, Kalyanaraman B, Radi R: Protein tyrosine nitration in hydrophilic and hydrophobic environments. Amino Acids 2007;32:501-515.

52 Radi R: Nitric oxide, oxidants, and protein tyrosine nitration. Proc Natl Acad Sci USA 2004;101:4003-4008.

-53 Victor VM, Nunez C, D’Ocon P, Taylor CT, Esplugues JV, Moncada S: Regulation of oxygen distribution in tissues by endothelial nitric oxide. Circ Res 2009;104:1178-1183.

54 Moncada S, Erusalimsky JD: Does nitric oxide modulate mitochondrial energy generation and apoptosis? Nat Rev Mol Cell Biol 2002;3:214-220.

55 Giulivi C, Poderoso JJ, Boveris A: Production of nitric oxide by mitochondria. J Biol Chem 1998;273:1103811043.

56 Navarro A, Sanchez Del Pino MJ, Gomez C, Peralta JL, Boveris A: Behavioral dysfunction, brain oxidative stress, and impaired mitochondrial electron transfer in aging mice. Am J Physiol Regul Integr Comp Physiol 2002;282:R985-992.

57 Tisdale MJ: Molecular pathways leading to cancer cachexia. Physiology (Bethesda) 2005;20:340-348.

58 Alberici LC, Oliveira HC, Patricio PR, Kowaltowski AJ, Vercesi AE: Hyperlipidemic mice present enhanced catabolism and higher mitochondrial atp-sensitive $\mathrm{k}^{+}$channel activity. Gastroenterology 2006;131:12281234. 